\title{
PENURUNAN KECEMASAN IBU DAN PERBAIKAN STATUS BANGUN-TIDUR BBLR MELALUI PERAWATAN METODE KANGURU
}

\author{
Qori'Ila Saidah $^{1,2^{*}}$, Yeni Rustina ${ }^{3}$, Nani Nurhaeni ${ }^{3}$ \\ 1. Jurusan Keperawatan STIKES Hang Tuah Surabaya, Jawa Timur 60244, Indonesia \\ 2. Program Studi Magister Fakultas Ilmu Keperawatan Universitas Indonesia, Depok 16424, Indonesia \\ 3. Fakultas Ilmu Keperawatan Universitas Indonesia, Depok 16424, Indonesia \\ *Email:qori_ht07@yahoo.com
}

\begin{abstract}
Abstrak
Kondisi klinis dan perawatan di ruang rawat intensif pada Bayi Berat Lahir Rendah (BBLR) mempengaruhi status banguntidurnya dan menyebabkan kecemasan pada ibu. Tujuan penelitian ini mengidentifikasi pengaruh perawatan metode kanguru terhadap kecemasan ibu dan status bangun-tidur BBLR. Rancangan penelitian one group pretest posttest design dengan sampel 16 ibu dan BBLR di sebuah rumah sakit Surabaya secara consecutive sampling. Kecemasan ibu diukur dengan PSS: NICU dan status bangun tidur dengan modifikasi skala Brazelton oleh Priya. Hasil analisis uji statistik menggunakan Wilcoxon Sign Rank Test dan uji Friedman menunjukkan ada perbedaan bermakna $(\mathrm{p}=0,000 ; \alpha=0,05)$. PMK mempunyai pengaruh signifikan terhadap perubahan kecemasan ibu dan status bangun-tidur BBLR. Tenaga kesehatan disarankan mengembangkan PMK untuk peningkatan status kesehatan ibu, juga tumbuh kembang bayi yang optimal.
\end{abstract}

Kata kunci: kecemasan ibu, perawatan metode kangguru, status bangun-tidur BBLR.

\begin{abstract}
Clinical condition and treatment at Low Birth Weight Infants $(L B W)$ in the intensive care unit affects sleep-wake status and causes anxiety for the mother. The aims of this study is to identify the influence of methods of kangaroo care on maternal anxiety and sleep-wake status of LBW. The design of this study was one group pretest posttest design with sample of 16 mothers and low birth weight in a hospital in Surabaya by consecutive sampling. Maternal anxiety was measured with the PSS: NICU and sleep-wake status with Brazelton scale modified by Priya. The result of statistical analysis test using Wilcoxon Sign Rank Test and Friedman test showed there are significant difference $(p=0.000 ; \alpha=0.05)$. KMC has a significant influence on changes in maternal anxiety and sleep-wake status of LBW. Health care provider are recommended to develop KMC for improvement of maternal health status, as well as the optimal infant growth and development.
\end{abstract}

Keywords: maternal anxiety, kangaroo mother care, sleep-wake state in low birth weight baby

\section{Pendahuluan}

Bayi berat lahir rendah merupakan permasalahan yang sering dihadapi pada perawatan bayi baru lahir. Tingginya angka Bayi Berat Lahir Rendah (BBLR) menjadi permasalahan tersendiri bagi tenaga kesehatan. Sekitar sepertiga dari jumlah BBLR meninggal sebelum stabil atau dalam 12 jam pertama kehidupan bayi. BBLR memerlukan perawatan yang intensif sampai berhasil mencapai kondisi stabil (Blackwell \& Cattaneo, 2006). Hasil Survei Demografi dan Kesehatan Indonesia (SDKI) 2002 - 2003 persentase BBLR di Indonesia menunjukkan 7,6\%. Menurut data Riset Kesehatan Dasar (Riskesdas) tahun 2007 (Depkes, 2008), sekitar $11,5 \%$ bayi lahir dengan berat badan $<2500$ gram atau BBLR.

BBLR termasuk didalamnya adalah bayi prematur. Bayi prematur mempunyai fungsi neurologis yang immatur. Bayi ini mempunyai permasalahan dalam kemampuan pengaturan, integrasi, dan koordinasi status bangun-tidur. Kesulitan yang dialami bayi mencakup jumlah waktu tidur tenang (quiet sleep), tidur aktif, dan jumlah fase transisi tenang. Hal ini terkait dengan fungsi dan kematangan neurologis. Pencapaian status bangun-tidur stabil dan transisi antara tiap fase merupakan tugas perkembangan utama pada minggu I kehidupan (Als, 1982, 1986 dalam Blackburn, Foreman, \& Thomas, 2008). 
Status bangun-tidur bayi merupakan bahasa bayi yang digunakan untuk mengekspresikan kebutuhan internal sebagai respon dalam kondisi lingkungan eksternal. Bayi yang mempunyai ambang kontrol yang rendah terhadap stimulus lingkungan akan sulit untuk mentoleransi stimulus lingkungan. Bayi dengan risiko tinggi terlihat mempunyai ambang yang rendah dan tidak mampu beradaptasi dengan stimulus yang berulang. Bayi mudah mengalami kelelahan terhadap stimulus yang didapat, sering terlihat kacau, mengalami henti nafas atau sering menangis. Reaksi ini menghalangi kemampuan bayi untuk memfokuskan diri terhadap isyarat dari lingkungan (Brazelton \& Nugent, 1995).

Kesulitan adaptasi terhadap lingkungan tampak pada status bangun-tidur bayi. Menurut Brazelton dan Nugent (1995), bahwa status bangun-tidur bayi terlihat dari tingkat aktifitas tubuh, pembukaan dan penutupan mata, keteraturan nafas, reaksi vokal, dan respon terhadap stimulus eksternal. Perkembangan status tidur bayi dikategorikan dengan adanya peningkatan status tidur tenang, penurunan status tidur aktif, peningkatan status terjaga, transisi antara status bangun-tidur yang tenang dan peningkatan kemampuan bayi untuk mempertahankan periode tidur seiring dengan peningkatan usia. Pada bayi prematur terjadi status yang tidak sama, bayi ini mengalami status tidur yang tidak jelas. Bayi terlihat mempunyai siklus tidur yang kurang, periode tidur yang lebih pendek, status tidur yang tidak jelas, dan periode tidur tenang lebih singkat (Blackburn, Foreman, \& Thomas, 2008).

Status bangun-tidur tenang sangat tergantung pada berat badan bayi (Ingersol dan Thoman, 1999 dalam Blackburn, Foreman, \& Thomas, 2008). BBLR mengalami status tidur tenang yang lebih singkat. Peningkatan jumlah tidur tenang bayi ini perlu dipikirkan dalam pengembangan pelayanan agar perkembangan bayi lebih optimal. Kedekatan bayi dengan orangtuanya dapat membantu peningkatan tumbuh kembang bayi. Namun demikian, bayi dengan BBLR sering kali memerlukan perawatan yang intensif sampai bayi stabil dan siap untuk mendapatkan perawatan di rumah. Bayi ini secara umum berada di ruangan khusus yang terpisah dengan ruang perawatan ibu. Perpisahan ini bisa menyebabkan kecemasan pada ibu tentang kondisi anak.

Menurut Ohgi, et al. (2002), isolasi dan perpisahan dengan orangtua akan mengurangi kesempatan interaksi antara orangtua dengan bayinya dan bisa menimbulkan stres pada interaksi antara ibu dengan bayi. Hal ini akan mempengaruhi perkembangan hubungan antara orangtua dengan bayi, yang dapat menghambat perkembangan bayi. Kondisi BBLR memerlukan lingkungan yang dapat membantu mengejar tumbuh kembang bayi. Interaksi dengan orangtua merupakan faktor terpenting. Orangtua memainkan peranan yang paling dominan dalam kehidupan bayi, terlebih karena perawatan di rumah sakit hanya bersifat sementara. Interaksi yang dekat antara anak dengan orangtua harus dimulai sejak dini, untuk itu perawatan perlu mengembangkan berbagai inovasi untuk meningkatkan kedekatan bayi dengan orangtua.

Perawatan bayi dengan metode kanguru (PMK) merupakan salah satu metode perawatan noninvasif yang memberikan keuntungan baik bagi bayi maupun ibu. PMK memfasilitasi interaksi yang dekat antara bayi dengan orangtua. Menurut penelitian Whilhelm (2005), PMK mempunyai efek signifikan pada temperatur payudara ibu, namun PMK secara statistik tidak menunjukkan efek signifikan dalam mempengaruhi penurunan kadar kortisol atau hormon stres ibu. Menurut Shiau (1997), PMK mempunyai efek yang signifikan dalam menurunkan kecemasan. Di Indonesia, penelitian tentang pengaruh PMK terhadap kecemasan ibu dan perkembangan perilaku bayi prematur masih terbatas sehingga masih diperlukan penelitian yang lebih mendalam.

\section{Metode}

Rancangan penelitian menggunakan QuasiExperimental Design dengan one group pretest posttest design. Namun, khusus untuk pengukuran status bangun-tidur bayi dilakukan dengan single subject design dengan repeated measurement. 
Sampel pada penelitian ini sebanyak 16 responden yang diambil dengan consecutive sampling. Kriteria BBLR yang menjadi responden adalah bayi prematur dengan $\mathrm{BB}<2500$, usia gestasi $31-36$ minggu, telah stabil dan tidak mengalami kelainan kongenital. Kriteria ibu adalah bisa membaca dan menulis, tidak sedang sakit selain nifas, dan badan ibu dalam keadaan bersih. Penelitian dilaksanakan di ruang neonatologi rumah sakit Surabaya pada Mei - Juni 2010.

Alat pengumpul data pada penelitian ini adalah menggunakan kuesioner data demografi, lembar observasi status bangun-tidur bayi dan kuesioner kecemasan. Data demografi klien dituliskan dalam kuesioner data demografi. Instrumen pengukur status bangun-tidur bayi yang digunakan adalah yang dikembangkan oleh Priya (2004). Pada instrumen ini status bangun-tidur bayi diberikan skor, mulai dari status bangun-tidur tenang (skor 6), tidur aktif (skor 5), mengantuk (skor 4), terjaga tenang (skor 3), terjaga aktif (skor 2), dan menangis (skor 1).

Pengukuran kecemasan ibu pada penelitian ini menggunakan instrumen Parental Stresor Scale: Neonatal Intensive Care Unit (PSS:NICU). PSS: NICU dikembangkan untuk mengukur persepsi orangtua terhadap stresor yang meningkat yang berasal dari lingkungan fisik dan psikis di NICU. Instrumen PSS: NICU terdiri dari 34 pernyataan tentang pengalaman atau situasi yang bisa terjadi terkait lingkungan NICU dan bayi. Pengalaman atau situasi dikelompokkan dalam tiga klasifikasi, yaitu pemandangan dan suara di ruang NICU, kondisi klinis dan perilaku bayi, serta hubungan orangtua dengan bayi dan peran orangtua. Penilaian hasil akhir kecemasan dari skor dilakukan dengan menggunakan metrik 2, yang merupakan penilaian tingkat stres secara keseluruhan.

Validitas dan reliabilitas instrumen dilakukan dengan uji Kappa dan back translation. Uji Kappa dilakukan untuk menyamakan persepsi antara peneliti dengan asisten peneliti terhadap hasil pengamatan status bangun-tidur BBLR. Hasil uji Kappa didapatkan 0,848 yang berarti tidak terdapat perbedaan persepsi antara peneliti dan asisten peneliti. Sedangkan back translation dilakukan terhadap PSS: NICU. Hasil back translation PSS: NICU menunjukkan bahwa tidak terdapat perbedaan yang bermakna dengan naskah aslinya sehingga cukup valid. Namun, hasil dari back translation tidak diujicobakan terlebih dahulu. Peneliti menggunakan nilai reliabilitas yang telah diujikan sebelumnya oleh penyusun PSS: NICU.

Pelaksanaan PMK dilakukan selama tiga hari. Pengukuran kecemasan ibu dilakukan pada hari pertama sebelum PMK dan hari ketiga setelah PMK. Pelaksanaan PMK dilakukan selama dua jam setiap hari. Pengukuran status bangun-tidur dilakukan pada menit ke-0, ke-60, dan ke-120 dari pelaksanaan PMK dengan menggunakan lembar observasi.

\section{Hasil}

\section{Karakteristik Responden}

Karakteristik responden ibu pada penelitian ini dapat dilihat pada tabel 1. Rata-rata usia responden 26,88 tahun dan sebagian besar responden berpendidikan SLTA. Jumlah responden dengan primipara sama dengan multipara masing-masing 8 responden. Sebagian besar responden melahirkan spontan $(68,8 \%)$ dan sisanya melahirkan secara SC (secaria caesar), dan sekitar $81,3 \%$ belum pernah mempunyai pengalaman melahirkan BBLR sebelumnya.

\section{Pengaruh PMK terhadap Kecemasan Ibu}

Tingkat kecemasan ibu sebelum dilakukan PMK adalah sebagian besar ibu mempunyai kecemasan sedang dengan jumlah 10 orang $(62,5 \%)$, ibu yang mempunyai kecemasan berat sebanyak empat orang (25\%), dan ibu yang mempunyai kecemasan ringan dua orang $(12,5 \%)$. Setelah dilakukan PMK jumlah ibu yang mempunyai kecemasan ringan sebanyak 12 orang $(75 \%)$, ibu yang mempunyai tingkat kecemasan sedang sebanyak empat orang (25\%), dan tidak ada yang mempunyai kecemasan berat (lihat tabel 2). 
Tabel 1. Karasteristik Responden

\begin{tabular}{|c|c|c|c|c|}
\hline Variabel & Mean & SD & $\begin{array}{l}\text { Minimal- } \\
\text { Maksimal }\end{array}$ & $95 \% \mathrm{CI}$ \\
\hline Usia Ibu & 26,88 & 3,26 & $21-32$ & $25,14-28,61$ \\
\hline Variabel & \multicolumn{2}{|c|}{ Frekuensi (f) } & \multicolumn{2}{|c|}{ Prosen tase $(\%)$} \\
\hline \multicolumn{5}{|l|}{ Pendidikan } \\
\hline SLTP & \multicolumn{2}{|c|}{1} & \multicolumn{2}{|c|}{$6,30 \%$} \\
\hline SLTA & \multicolumn{2}{|c|}{11} & \multicolumn{2}{|c|}{$68,80 \%$} \\
\hline $\mathrm{PT}$ & \multicolumn{2}{|c|}{4} & \multicolumn{2}{|c|}{$25 \%$} \\
\hline \multicolumn{5}{|l|}{ Paritas } \\
\hline Primi & \multicolumn{2}{|c|}{8} & \multicolumn{2}{|c|}{$50 \%$} \\
\hline Multi & \multicolumn{2}{|c|}{8} & \multicolumn{2}{|c|}{$50 \%$} \\
\hline \multicolumn{5}{|l|}{ Jenis Persalinan } \\
\hline $\mathrm{SC}$ & \multicolumn{2}{|c|}{5} & \multicolumn{2}{|c|}{$31,30 \%$} \\
\hline Spontan Normal & \multicolumn{2}{|c|}{11} & \multicolumn{2}{|c|}{$68,80 \%$} \\
\hline \multicolumn{5}{|c|}{ Pengalaman sebelumnya } \\
\hline Pernah & \multicolumn{2}{|c|}{3} & \multicolumn{2}{|c|}{$18,80 \%$} \\
\hline Tidak pernah & \multicolumn{2}{|c|}{13} & \multicolumn{2}{|c|}{$81,30 \%$} \\
\hline
\end{tabular}

Setelah dilakukan uji Wilcoxon sign rank test didapatkan secara statistik terdapat perbedaan yang bermakna antara tingkat kecemasan ibu sebelum dan setelah PMK $(p=0,000, \alpha=0,05)$.

\section{Pengaruh PMK terhadap Status Bangun-Tidur}

Status tidur bayi pada hari pertama menunjukkan bahwa variasi yang beragam. Pada menit ke-0 hari pertama, sebagian besar sekitar 9 bayi berada pada status tidur aktif $(56,25 \%)$. Bayi dengan status tidur tenang dan status mengantuk hanya dua bayi $(12,5 \%)$, sedangkan yang lainnya bervariasi antara status menangis, terjaga aktif, dan terjaga tenang, yaitu masing-masing satu orang $(6,25 \%)$.

Pada menit ke-60, bayi yang mengalami status tidur tenang sebanyak sepuluh bayi $(62,5 \%)$. Bayi yang mengalami status tidur aktif empat bayi $(25 \%)$, dan terdapat masing-masing satu bayi $(6,25 \%)$ dengan status terjaga tenang dan mengantuk. Pada menit ke-120 terdapat 13 bayi $(81,25 \%)$ yang mengalami status tidur tenang dan lainnya yaitu sebanyak tiga bayi $(18,75 \%)$ mengalami status tidur aktif.
Status tidur bayi pada hari kedua menit ke-0 masih didominasi oleh status tidur aktif. Jumlah responden dengan status aktif pada menit ke-0 sebanyak 12 bayi (75\%). Responden dengan status tidur mengantuk sebanyak tiga bayi $(18,75 \%)$. Responden dengan status terjaga aktif satu bayi $(6,25 \%)$. Tidak ada responden yang mempunyai status tidur tenang, terjaga tenang maupun menangis. Pada menit ke-60 terdapat tujuh bayi $(43,75 \%)$ dengan status tidur aktif dan sembilan bayi $(56,25 \%)$ dengan status tidur tenang. Pada menit ke-120 terdapat 15 bayi $(93,75 \%)$ dengan status tidur tenang dan lainnya satu bayi $(6,25 \%)$ mempunyai status tidur aktif.

Pada hari ketiga menit ke-0 sebagian besar bayi mengalami status tidur aktif sebanyak tujuh bayi $(43,75 \%)$. Terdapat tiga bayi $(18,75 \%)$ dengan status tidur tenang, tiga bayi $(18,75 \%)$ dengan status terjaga tenang, dua bayi dengan status mengantuk, dan satu bayi $(6,25 \%)$ dengan status terjaga aktif. Pada menit ke-60 terdapat perubahan status tidur bayi. Bayi dengan status tidur tenang sebanyak 14 bayi $(87,5 \%)$ dan dua bayi $(12,5 \%)$ mempunyai status tidur aktif. Pada menit ke-120, 
Tabel 2. Distribusi Frekuensi Kecemasan Ibu Sebelum dan Setelah PMK

\begin{tabular}{lcccc}
\hline \multirow{2}{*}{ Kecemasan } & \multicolumn{2}{c}{ Pretest } & \multicolumn{2}{c}{ Posttest } \\
\cline { 2 - 5 } & $\mathbf{n}$ & $\boldsymbol{\%}$ & $\mathbf{n}$ & $\mathbf{\%}$ \\
\hline Cemas ringan & 2 & 12,5 & 12 & 75 \\
Cemas sedang & 10 & 62,5 & 4 & 25 \\
Cemas Berat & 4 & 25,0 & - & - \\
\hline
\end{tabular}

jumlah bayi dengan status tidur tenang sebanyak 15 bayi dan bayi dengan status tidur aktif hanya satu bayi $(6,25 \%)$.

Hasil uji Friedman menunjukkan hasil yang baik pada hari pertama, kedua maupun hari ketiga $(\mathrm{p}=$ $0,000, \alpha=0,05)$. Berdasarkan interval kepercayaan 95\%, dapat disimpulkan bahwa terdapat perbedaan yang signifikan pada status bangun tidur bayi hari pertama, kedua, dan ketiga pada menit ke-0, ke60, dan ke-120 $(\alpha=0,05)$. Selanjutnya, dilakukan post hoc dengan Wilcoxon Sign Rank Test untuk mengetahui perbedaan status bangun-tidur pada tiap menit pengukuran yang digambarkan pada tabel 3 .

\section{Pembahasan}

Bayi dengan pertumbuhan dan perkembangan yang optimal akan mampu mengontrol stimulus yang datang dengan merubah berbagai status banguntidur. Sebagian besar bayi meng-alami status tidur aktif saat bayi tidak dapat tidur dengan nyenyak. Pada tahap ini pertumbuhan dan perkembangan BBLR kurang optimal dibanding bayi aterm yang mampu menghabiskan sebagian besar waktu dengan tidur tenang. Tidur tenang merupakan fase tidur yang mampu memfasilitasi pertumbuhan dan perkembangan secara optimal.

Berbagai metode untuk memfasilitasi fase tidur bagi bayi perlu diperhatikan karena merupakan hal penting bagi pertumbuhan dan perkembangan bayi. Hal ini sesuai penelitian yang dilakukan oleh Shiau (1997) yang mengungkapkan bahwa PMK mempengaruhi penurunan hormon stres pada bayi dan ibu. Penurunan hormon stres bayi dapat dilihat dari fase tidur tenang.
Perawatan metode kanguru dapat mempengaruhi status bangun-tidur pada bayi melalui perubahan hormonal. Kedekatan antara ibu dan bayi melalui kontak kulit menimbulkan rasa aman pada bayi sekaligus dapat mempengaruhi status hormon stres. Selanjutnya, hormon ini akan mempengaruhi penurunan terhadap jumlah konsumsi energi yang sebelumnya digunakan untuk merespon dan mengontrol stimulus lingkungan. Kecukupan energi ini disebabkan peningkatan aliran darah ke otak yang berdampak pada peningkatan suplai oksigen dan nutrisi ke otak. Kondisi ini membantu bayi mencapai status tidur tenang lebih lama.

Pada pelaksanaan observasi menit ke-60 masih banyak ditemukan bayi dengan status tidur aktif. Perawatan metode kanguru dapat membantu bayi untuk mencapai tidur tenang. Hal ini terlihat pada menit ke-120, yang sebagian besar bayi berada pada status tidur tenang. Pada menit ke-60 bayi masih mengalami satu siklus tidur, namun beberapa bayi telah mencapai tidur tenang.

Perubahan jumlah bayi yang mencapai tidur tenang tidak banyak sehingga ketika dilakukan uji statistik tidak menunjukkan hasil yang signifikan. Hal ini sesuai dengan penelitian Browne dan Graven (2008), yang menjelaskan bahwa pada satu siklus tidur beberapa bayi telah mencapai tidur tenang.

\section{Kesimpulan}

Perawatan metode kanguru yang merupakan tindakan noninvasif telah mempunyai pengaruh yang signifikan terhadap kecemasan ibu yang mempunyai BBLR prematur. Perawatan ini juga mempunyai pengaruh yang signifikan terhadap status bangun-tidur BBLR. 
Tabel 3. Distribusi Frekuensi Status Bangun-Tidur BBLR

\begin{tabular}{lc}
\hline \multicolumn{1}{c}{ Frekuensi } & $\begin{array}{c}\text { p (95\% CI) } \\
\text { Status Bangun-Tidur }\end{array}$ \\
\hline Hari I & 0,005 \\
- Menit $0-60$ & 0,234 \\
- Menit $60-120$ & 0,002 \\
- Menit $0-120$ & \\
Hari II & \\
- Menit $0-60$ & 0,001 \\
- Menit $60-120$ & 0,034 \\
- Menit $0-120$ & 0,000 \\
Hari III & \\
- Menit $0-60$ & \\
- Menit $60-120$ & 0,001 \\
- Menit $0-120$ & 0,157 \\
\hline
\end{tabular}

Perawatan bayi dengan BBLR perlu dikembangkan lebih baik agar proses tumbuh kembang bayi lebih optimal. Keberadaan perawatan metode kanguru tersebut, sedikit banyak membantu mengurangi tingkat kecemasan dan memperbaiki status banguntidur bayi. Penelitian yang lebih mendalam perlu dilakukan terhadap respon bayi BBLR dan ibu dalam masa tumbuh kembang bayi. Selain itu, perlu diperhatikan juga bahwa perawatan yang baik dengan fasilitas yang mendukung bagi ibu dan bayi BBLR (WK, NN, DW).

\section{Referensi}

Blackburn, T.S., Foreman, W.S., \& Thomas, A.K. (2008). Preterm infant state development. Jurnal of Obstetric, Gynecologic, \& Neonatal Nursing, 37 (6), 657-665. Doi: 10.1111/j.1552-69 09.2008.002 92.x.

Blackwell, K., \& Cattaneo, A. (2006). What is the evidence for kangaroo mother care of the very low birth weight baby? Diperoleh dari http:// www.ichrc.org/pdf/kangaroo.pdf.

Brazelton, T.B., \& Nugent, J.K. (1995). Neonatal behavior assessment scale (3rd Ed.). London: The lavenham Press Ltd., Mac Keith Press.
Browne, J.V., \& Graven, S.N. (2008). Sleep and brain development. Diperoleh dari http:// www.wonderbabiesco.org/UserFiles/File/ Graven $\% 20$ and $\% 20$ Browne $\% 20$ sleep $\%$ 2008.pdf.

Depkes, RI. (2008). Laporan nasional riset kesehatan dasar (Riskesdas) tahun 2007. Jakarta: Badan Penelitian dan Pengembangan Kesehatan, Depkes RI.

Ohgi, et al. (2002). Comparison of kangaroo care and standart care: behavioral organization, development, and temperament in healthy, low birth weight infant through 1 year. Journal of Perinatology, 22, 374-379. Doi: 10.1038/ sj.jp.7210749.

Priya, J.J. (2004). Kangaroo care for low birth weight babies. The Nursing Journal of India, 95 (9), 209-212.

Shiau, S. H. (1997). Randomized controlled trial of kangaroo care with fullterm infants: Effects on maternal anxiety, breastmilk maturation, breast engorgement, and breastfeeding status (Thesis Master, Case Western Reserve Univer-sity). Case Western Reserve University, Cleve-land, USA. Diperoleh dari http:/ /neoreviews.aappublications.org/cgi/reprint/ neoreviews;8/2/e55.

Whilhelm, P. A. (2005). The effect of early kangaroo care on breast skin temperature, distress, and breastmilk production in mothers of premature infants (Dissertation, University of Nebraska Medical Center). University of Nebraska Medical Center, Omaha, NE, USA. Diperoleh dari http://www.newbornnetworks. org.uk/southern/PDFs/KangarooCareFinal. pdf. 